\title{
Practice of Propaganda on Korean Peninsula (1945-1960)
}

\begin{abstract}
The topic of propaganda, which was thought to be a part of the Cold War past, was recently revived by modern and rather successful application in Georgian, Syrian and Ukrainian conflicts. In this regard Korean Peninsula is a perfect example of prolonged use of mutual practice of indoctrination to study its origins. This article discuses the evolution of propaganda use by both Democratic People's Republic of Korea and Republic of Korea (1945-1960) in cultural, economic and political dimensions. Qualitative text analysis and case study in conjunction with theoretical framework of A. E. Cassirer, S. Langer, E. Barneys and W. Lippmann are used to establish techniques used, and to explain its overall success.
\end{abstract}

\begin{abstract}
Ukrainian): До недавнього часу тематика пропаганди певною мірою вважалася закритою і вивчалася як частина Холодної війни але сучасні події у Грузії, Сирії та Україні продемонстрували іï ефективність і зараз. Корейський півострів це чудовий приклад довготривалого взаємного використання практики індоктринації для успішного вивчення походження цього явища. У цій статті описується еволюція у використанні пропаганди Корейською Народно-Демократичною Республікою і Республікою Корея (1945-1960) у культурній, економічній та політичній сферах. Якісний аналіз текстів і кейс-аналіз використовуються у поєднанні з теоріями Е. Кассірера, С. Ланджер, Е. Бернейза та У. Ліппмана, щоб встановити використані техніки і пояснити їх загальну успішність.
\end{abstract}

Keywords: Korea, ROK, DPRK, Propaganda, Indoctrination, Korean War

\section{Introduction}

Propaganda is one of the most complex and rather unexplained phenomena's in modern international relations. It was present in different forms probably since the first human communities, but only in recent centuries it grew in scope tremendously by gradually adopting the new technologies of mass communication. The positive and negative sides of spreading preconceived information with the intent to mislead the opponent or to create some type of illusion have already been widely discussed and analyzed in the framework of pre- and post-World War II periods.

The reemergence of the use of this tool and its relative success in recent years, surrounding several conflicts in Georgia and more recently in Ukraine and Syria, started to raise the new questions on why is it still effective in 
some presumably more developed societies of XXI century. In this regard, the experience of Korean peninsula is a unique opportunity to study a continuous change in techniques of and reactions to propaganda during the prolonged period of more than 60 years, making it a relevant topic for a modern research.

This article attempts to cover questions on whether occurrences of propaganda influenced the relations of both Korean states before, during and immediately after their division, and how it changed in relation to mentioned periods.

The current effective use of propaganda techniques, presumably conceived during the first part of XX century, and the overall inability to counter it by modern societies makes this topic's novelty. At the same time Korean experience is less explored compared to other Cold War topics, but the relevance for study of propaganda on its example is evident when looking at the timeframe this phenomena have been present on the peninsula. The mentioned period of 1945-1960 is suitable for the initial research of propagandistic behavior before, during and after the war in a pre-contemporary society with no means of modern communication technologies.

The aim of this article is to establish the linkage between the propagandistic activity and its influence on relations (or the absence of such) between the two states - Democratic People's Republic of Korea and Republic of Korea.

Most of the sources concerning the period close to the Korean War focus either exclusively on the relations with the West and the USA (or even within the USA with the regard to Korean conflict perception there) in particular, or Korea as just another battlefield for Cold War era influence spheres. At the same time there is scarce information on the relations between the divided parts of the peninsula in the aftermath of war and the use of propaganda outside of Cold War framework, making it difficult to explore its extensive use on this separate occasion contributing to the problem of the research.

This research is a qualitative study that uses combination of text, discourse analyses and case study. Such approach is relevant due to a scarce quanititive data availiable for the researched period and a limited number of Englishlanguage sources directly dealing with the issue. Texts dealing with political, economic and cultural events of this timeframe are analysed to trace the change in the propagandist discourse of the two opposing regimes through the course of the conflict. Case study is also employed in order to showcase situation in politics of North Korea.

This is achieved by subjecting empirical knowledge in the form of texts on economic, political and cultural life in Republic of Korea and Democratic People's Republic of Korea during the period of 1945-1960 to the theoretical frameworks of A. E. Cassirer, S. Langer, E. Barneys and W. Lippmann. Conditions, means and results of the propaganda practice are discussed, as well as grounds for the future developments regarding the issue. 


\section{Conception of propaganda}

According to Merriam-Webster dictionary the definition of propaganda is as follows: "Ideas or statements that are often false or exaggerated and that are spread in order to help a cause, a political leader, a government, etc." (Merriam-Webster Online Dictionary). Oxford dictionary gives similar interpretation citing that it is "Information, especially of a biased or misleading nature, used to promote a political cause or point of view" (Oxford Online Dictionary). Both treatments are correct employing the same notion of the use of false information to promote certain ideas.

However, the conception of propaganda is much more complex than that, when it comes to the real life experience and human perceptions. There are several types of propaganda to be distinguished corresponding to the spheres where they are employed with the most common to be: political, religious, and educational. At the same time there are certain subtypes that can be identified, as with the political propaganda that adopts according to the context of political process (or the absence of such, as in the event of war). All in all, there is no clearly defined concept of propaganda as most of the existing techniques are used simultaneously in several spheres at once creating different product each time.

The study of propaganda can be conducted from the perspective of question whether there is or there is no such thing at all, but this can be deemed unconstructive since its concept offers an alternative look at particular events, which to a certain degree appeals to all human beings. In such a case there is no certainty in any of the results taken from propaganda research because of ever-persisting human factor and a degree of bias.

As for the tools employed in modern propaganda the common media play the most definitive role by the use of the most available means (depending on the timeframe and society) of communication, including television, internet, radio, printed press etc. In this particular case represented in the research, the tools are rather restricted to printed sources and radio. Historical revision, dehumanization of the enemy, blackmailing etc. are just the examples of the reoccurring topics in propagandistic activity of the last century and which are still being used.

In case of Korean peninsula the post-World War II events were influenced by propaganda the most, splitting homogenous society into two. The overall concept at the time was changed from the political competition to the war framework and back to politics again, changing tools and perpetrators in the process.

Therefore, there are several approaches to the study of the impact of information, communication, and public relations to explain their applicability in this certain instance. 


\section{Role of myth and reality}

The concept of myth and its impact on public is best explained by A.E. Cassirer and S. Langer, both forming a theory that can be used in researching propaganda via symbolism, language and psychological attachment of human beings to certain images. It is crucial to understand that propaganda does not appeal directly to a common logic, but rather offers a suggestion for a person to build connections by himself. In result it creates a certain blur of facts and especially ideas formulated upon pre-conceived and uncontested knowledge that largely influences how we perceive the world that surrounds us. At the same time it is hard to separate one informational fact from the whole propagandistic discourse that allows us to gradually study the formation of so-called "alternative reality" that gradually expands the boundaries of perception, and is deemed illogical to an outsider not familiar with it.

Cassirer's and Langer's work was based on two notions that "if ignorance is a negative condition; why should the mere absence of correct conceptions lead to misconceptions?" And that "...why should language, supposedly a practical instrument for conveying thought, serve to resist and distort scientific thought?" They thought that since science requires a certain rigid type of thinking to exist, based on facts that the idea of misconception means that there might be more of other modes of thinking. Language in this regard is a tool, functioning to allow this to happen by giving preference and support.

There is no such thing as wrong way of thinking as all thinking is realistic by default. He argues that humans are able to either observe or to think forming the modes of thinking. Observation gives a factual knowledge of a certain event, logically connecting known facts to it. Thinking, on the other hand, brings the discourse connected to the said event by bringing all of the mentioned uncontested knowledge referring either to divine or mythological perspectives (Cassirer and Langer 1946, p.7). Language can be called an exclusive product of thinking, as it is incompatible with scientific approach to reasoning. Thinking here offers a mode where person is able not only to assess logical data, but also to experience concepts of "see" and "feel" (Cassirer and Langer 1946, p.10).

In certain way propaganda in its various forms allows a consumer to relive certain events without participating in them or even without knowing basic facts by substituting them with experience attached to words. Those additional meanings are seen as positive rather then negative forms of understanding for the bearer. In this regard language has a poetic form of storytelling making it hard to find that connection back to fact-based scientific knowledge. This is very much in line with S. Langer's thinking of spontaneous and most of all unconscious process of abstraction attributed to human mind, creating new storylines in different socio-linguistic configurations.

In Langer's and Cassirer's theory there is also a notion of an actual "reality". They think that former civilizations dealt with the real world more than current 
generations, functioning in a deeply interconnected world of additional meanings and myths accumulated during centuries. Causal relationships to meanings are impossible to separate with the passing time. For Cassirer's and Langer's worldview the coming back to an older reality was predefined by their own predecessors from metaphysics school forming an idea of a "spirit building a physical world for itself". They argue that language revolves around substance and attribute while science tends to distance itself from it by utilizing the concept of function ultimately employed in mathematics.

The meaning of the object fluctuates in the language framework; therefore, the concept of name is used to pinpoint an exact point of experience. There is a connection between having a name and evoking an emotion, or an additional meaning to start the process of image making - the imagination. Imagination is not logical and requires a discourse to survive, creating its own logic, identities, and feelings crammed in one symbol. In turn, symbols become instruments of conception, so often employed in propaganda. It happens because symbolic image is conceived instead of just physiologically remembered. According to Cassirer and Langer, there are a number of symbolic forms in existence, including the language itself, myth, art and science. Myth and language appear to be born at the same time in human mentality expressing primitive world in their own way. Mythical thinking is clearly not permanent utilizing divine elements and immaterial beliefs of the early ages. To some extent, it can be called a dream element allowing supernatural phenomenon to exist alongside facts. Devine background of a single act forms a notion of holiness behind certain things or events delivering preconception of inherent power attributed to it.

Practical experience is not the only source of knowledge for a human being, but the mythical side, interpretation of reality with the help of existing symbols imported on such occasions. Propaganda uses this feature to substitute knowledge with imagination triggered by the symbols generally inherent to target audience. By forming words into sentences people start a race of interpretations creating a discursive thought or what is usually called "reason". Reasoning adds an additional sparkle to propaganda by achieving self-told stories behind each and every piece, allowing consumers to create their own version of events, things. Associations and formation of "things" is widely seen in modern society via old beliefs, traditions and ever-lasting religious dogmas, sometimes creating irrational motivation.

\section{Synthesis of propaganda and public relations}

Propaganda as a phenomenon is usually exclusively attributed to various abusive political regimes; however, certain practices exist in democratic and liberal democratic configurations of politics, with media and social relations having the same goal of producing confusion or part-truth material. This occurrence is rarely distinguished from the propaganda practice in undemocratic 
societies, but sometimes is called "public opinion" or its formation to be precise. The key difference here is the social and political structure of the given community allowing to use either constructed and restricted information sphere, controlled solely by the state, or to manipulate the existing media bodies in telling the exact and "correct" message with predictable impact on the audience, though having a risk of competition.

This notion is at least marginally important in relation to studying South Korea's performance during the researched timeframe. Even though the most time of this period is characterized by overall authoritarian rule of Syngman Rhee, there was also a tremendous degree of pressure from the USA and a brief period of United States Army Military Government in Korea (USAMGIK), which, in turn, was heavily influenced by domestic politics of the USA.

One of the first and most prominent conscious theorists and practitioners of the propaganda in the democratic society was Edward Barneys, stirring public opinion both in marketing and the USA politics (prominently including foreign relations) alike. He is prominent to use psychoanalysis, a creation of his uncle Sigmund Freud for this purpose.

For him public relations are a highly manipulative field, allowing for various businesses and governmental agencies to influence their position in the food chain. Here E. Barneys attempts to create a framework suitable to control public opinion in a [liberal] democratic society. He starts with the idea of organizing chaos of public relations. They seem to be a natural result of the democratic society organization, where a number of human beings have to cooperate to facilitate a creation of functioning society (Barneys 2004, p.9).

Structurally, democracy tends to achieve an opposite of the declared goal of the rule of the majority. Instead, public relations provide an opportunity to turn this idea around and to establish a rule of a minority in key social positions that is highly aware of and masterful in practicing them. According to Barneys: "There is consequently a vast and continuous effort going on to capture our minds in the interest of some policy or commodity or idea. It might be better to have, instead of propaganda and special pleading, committees of wise men who would choose our rulers, dictate our conduct, private and public, and decide upon the best types of clothes for us to wear and the best kinds of food for us to eat. But we have chosen the opposite method, that of open competition. We must find a way to make free competition function with reasonable smoothness. To achieve this society has consented to permit free competition to be organized by leadership and propaganda" (Barneys 2004, p.11)

Psychologically he argues that this is possible, thanks to the different mental characteristic of an individual and that of a group. Therefore, a group is influenced by certain emotions and impulses differently that an individual. He argues that if a group psychology can be understood, then it can be manipulated. For Barneys psychology is not an exact science but a tool to 
a limited practice of propaganda. A man is considered to be a member of a "herd" and is expected to follow certain predictions in his behavior. The power of propaganda is such as to convince a human being of something, without him consciously making a connection to an outside interest, which is actually directing the line of thought. In this condition the good impression has more weight then an actual reality making it possible to sell a less advanced product or to amass support for a less logical idea.

He devotes a high degree of attention to the influence of social groups in an effective propagandist campaign. In his argument E. Barneys mentions a business related case of thinking behind the selling of soap by the Procter and Gamble Company. According to him, the mentioned venture had a goal of increasing soap revenues. For this purpose a soap-sculpture contest was organized throughout the USA under the umbrella of Art Center in New York City. Several social groups were defined to be influential on the success of this endeavor including schoolteachers, mothers of the children and culture related figures. The teachers were happy to receive educational aid for schools. Mothers, at the time, were then presumed to already possess certain quantities of soap and were naturally interested in their children development. And the judges were selected upon the good evaluation of an ivory soap as a good sculpture material and also by securing the support of a prestigious art gallery in New York. A number of psychological motives were started to carry out the campaign (esthetic, competitive, gregarious, snobbish, exhibitionist and maternal).

The group structure itself helped to start this project as positions of leadership and authority were interested in following the agenda established by the company. Eventually, the competition brought necessary attention and a number of entrances had risen dramatically throughout the course of campaign adding to the sales (Lipmann 1965, pp.58-60).

The mentioned case is a great example of complex nature of propaganda, also characteristically applicable to the political sphere. The notion of social strata in influencing general populace was highly used by North Korean side and it is inherent to communist regimes overall, encompassing workers and peasants as a driving force at different times.

\section{The role of human logic and meanings}

Throughout the history there existed a number of examples on illogical conduct. According to Walter Lippmann, among those are inquisition and its witch-hunts, the burning of the library in Alexandria and people thinking that they will become rich by always selling and never buying (Lipmann 1965, p.5). He argues that for such examples there should be an explanation allowing such turn of events, where a number of wrongful perceptions will lead to an outmost conviction in one's own righteousness. 
Walter Lippmann references a small limit of human's perception: "Whether we regret this as one of the soft evils of peace or applaud it as a return to sanity is obviously no matter here. Our first concern with fictions and symbols is to forget their value to the existing social order, and to think of them simply as an important part of the machinery of human communication. Now in any society that is not completely self-contained in its interests and so small that everyone can know all about everything that happens, ideas deal with events that are out of sight and hard to grasp" (Lipmann 1965, p.7). Therefore, the image of an event is more valuable than the event itself to the external actor.

The nature of human perception is that it mostly relates to the experience and the simple truth is that even the biggest developments in the country's life are experienced only by a certain number of citizens. Thus, public opinion is used to substitute this general absence of experience and to draw personal attachment to the said event, based on the previous common experience of the person and the actual participant. In the relation to Korea, particular moves were made to establish the cult of the personality along such framework in the DPRK and to a certain extent in ROK too, by introducing a general discourse of Korean nationalism to establish the position of the new and relatively unknown leaders to the Korean public.

In many ways Walter Lippmann's approach is also attributed to democratic states, where a chance for the public disclosure of materials is higher and a certain political responsibility exists. However, it is possible to produce a more convincing message in a controlled information environment, typically possible during implementation of the state of emergency in democracies in the event of war or the prolonged structures of authoritarian state.

For the purpose of showing such conflict of reality and image, he presents a case from a World War I period. At the time composition of communiqués by the general's stuff was to some extent more regular than the actual war planning. During the battle of Verdun an unexpected issue occurred as a small German force took a fortress from a small French garrison in a close proximity to the Entente lines. The precedent resulted in a discussion on how to inform the public and finally deciding to explain it through constructing an imaginary battle: "A bitter struggle is taking place around Fort de Douaumont which is an advanced post of the old defensive organization of Verdun. The position taken this morning by the enemy, after several unsuccessful assaults that cost him very heavy losses, has been reached again and passed by our troops whom the enemy has not been able to drive back" (Lipmann 1965, pp.15-16). This message prompted a large number of military writers to follow on official information, even though it was unconfirmed from any other sources thus showing the break in information verification at the time.

Such practice is heavily influenced by the available recourses, which, in turn, allow to mobilize the public in either active (voluntary enlistment into the army or public work etc.) or passive support. A web of communication 
devices and tools should be conceived to assure constant pressure on the public. In the USA a number of papers and radios worked together in order to promulgate its entrance into the war in Europe at the time. The structure of messages was also to be clean and simple with certain pace and repetition as main tools of influencing right reactions and creating envisioned picture. Stereotypes, codes are also a part of Lippmann's theory defining them as an already existing public knowledge capable and through which it is possible to achieve common ground in either support or opposition for certain issue.

\section{Provisions of propaganda on the cultural level in DPRK and ROK}

The Korean conflict and war are mostly attributed to the overall Cold War, which was raging at the time, with little interest in actual situation on the ground, leaving Korea to be a "black box" of international relations. Currently attempts are made to break this illusion of secondary importance. To start off this dialogue the culture of Korea is employed as mechanism capable of understanding as well as controlling Korean realities.

On Korean peninsula, as overall in Asia, the Cold War had a much hotter degree than that of European continent. Before the actual war there were two occupational governments established in the aftermath of Japanese withdrawal. The USA established Army Military Government in Korea (USAMGIK) to oversee elections and a peaceful transition of the government. Correspondingly, Soviet Union facilitated creation of provisional government. In both cases huge military contingents were maintained until 1948.

The years prior to the war of 1950-1953 were characterized as propagandist war or the "brainwashing", a term coined during this time. It is necessary to understand that the occupying forces were engaged in the constant international struggle that changed its degree upwards since 1945. This change was also evident in cultural warfare and in the development on the peninsula.

According to Charles K. Armstrong, "We can trace roughly three stages in U.S. cultural policy toward Korea between the Japanese surrender and the Korean War: a period of apathy, from August 1945 to the end of 1946; alienation, in which a growing number of intellectuals became disillusioned with the U.S. occupiers and moved north to the Soviet zone, from early 1946 to mid-1947; and activism, with the U.S. occupiers finally paying serious attention to the problems of propaganda and information, from mid-1947 to 1950" (Armstrong 2003, p.74).

These periods correspond to the actions of the U.S. government quite soundly. During this time communist were already known to establish highly sophisticated procedures for indoctrination or, simply put, propaganda. Korea at the time was an agricultural state highly susceptible to such practice. However, it took some time for the USAMGIK to understand this notion and to start its own campaign for "hearts and minds". 
Various forms of art fit the purpose of establishing the system of propaganda machine, including theater, film, radio and film. With the increase of tensions between the USA and Soviet Union, the industry of deception grew in the former. In this regard Soviet Union was far ahead of its rival, having an enormous experience of "korenizatsiya" policy conducted throughout its republics (Baron 2004, p.447). Therefore, it took time for the USA to realize its position and to think on countering it.

First stages of occupation did not include any particular specialization for the Korean territory in any regard, as the U.S. authorities did not have enough experience at the time (presently a certain transition of superpower status was in motion, the UK having a superior degree of understanding of the ongoing conflict) (Shaw 1999, pp.263-281). The Japanese administrators were retained in most cases, including the educational system. This resulted in much discontent by the students, participating in regular strikes, with certain assumptions being made upon Japanese departure. Also the left-right discourse had a tremendous impact in the society then, resulting in domestic conflicts and dismissal or resignation of leftist professors from the educational bodies.

At certain point, the U.S. authorities decided on providing the education for Koreans at the universities in the U.S. as a way to counter communist ideals in the deeply divided country. But it seems as the issue was not as evident then as it is now, since even such initiative took a number of years to be implemented, having the office for the famous Fulbright program opened in 1950 but the exchange delayed up until after the war. The Soviet approach in this regard was much blunter as a number of Korean students were almost instantaneously encouraged to enroll into universities (Armstrong 2003, p.76).

The effect of polarization of the art world was evident, as public opinion was driven just short of anti-leftist hysteria. Many artists were either harassed or denied jobs and performances, based on their political alignment. The employment problem was not only limited to the "political" artists, but also to the others as the USAMGIC was not interested or even tasked with such goal. At the same time, according to Ely Haimowitz, a worker of USAMGIC Department of Education "[t]he Soviets in North Korea make a policy of sending the finest Korean talent to the USSR" (Armstrong 2003, p.77). Ignoring the issue resulted in a large number of culture-related specialists to leave for North as simply a means to survive.

The second stage was connected to the realization of the contemporary situation, as previously abolished Office of War Information was revived by 1947 . A body for the conduct of propaganda was finally established and the United States Information Service (USIS) offices were opened in Seoul, Pusan, Inchon and others. The USIS structure was to employ staff of ten to thirty Koreans and two Americans. The structure also included a production unit in Seoul (Armstrong, 2003, p.78). At the time a mobile motion picture groups were finally organized. By the end of 1948 the U.S. began a full- 
scale production of documentary films and their subsequent dissemination within controlled territory. The problem experienced then was that the agents sent to establish the Korean film industry were actually representatives of a commercial wing and thus had little interest in re-education efforts set by the governing bodies. Additional problems existed with the availability of the equipment to successfully disseminate materials.

A low-rate and low-quality production called for the translation of existing materials from the WWII times, which was rather unfit for the local population. Certain degree of Soviet produced films were allowed to be shown, mostly by the Soviet consulate in Seoul. However, the abuse of this right became a reason for the closure of the consulate, as it was seen as an ideological attack from within.

In North Korea propaganda played a more serious role from the beginning of the occupation. It is best depicted by the overall success in gathering support from local art world. The period was brief, just under two years, eventually going into state-controlled phase, but was crucial in attracting a number of valuable personalities from the South.

On the school level, Russian language surpassed English as a means of international communication. Nationalism in education was endorsed while Soviet literature was translated and educational materials were provided, contrary to the Southern experience that continued to use colonial-era textbooks. American policy in ROK was mostly concerned with the preservation of the image of the USA, whereas Soviet approach devoted most attention to local initiatives, while only slightly influencing the content of published materials. The USSR also had a relatively high number of native Koreans, who were previously deported in 1937 from the Far East to the Central Asian republics and who may have been instrumental in facilitating communication and education (Gelb 1995, pp.389-412).

North Korean government was responsible for a number of educational reforms during the researched period. Firstly, in 1946 a general education system was formed to comprising of five-year People's school, a three-year junior high school and a three-year senior high school. Additionally, a three to four specialized secondary high schools were created to provide technical education. The university of Kim Il-sung was also created. The emphasis was made heavily on technical education as the country lacked highly educated engineers due to the withdrawal of Japanese empire personnel. This commitment was also supported by the expansionist goals of the regime culminating in 1950 and helping to produce war machinery (Hyung-Chan 1969, pp.831-836). Additional adjustments were made in 1953 and 1959 gradually transforming education in ideology-driven practice (Hyung-Chan 1969, p.836).

The education system also used a target-group approach, explained by E Barneys as the preference for the education, was given to children of the 
peasants and mainly workers. In both countries a national writing system of Hangul was gradually introduced in order to replace Chinese characters. Among other differences in education, the Northern side provided a free education contrary to the South's profit-making approach, thus creating a certain vacuum for the development of bright children.

It is an interesting thing to note, that the general approach of the Soviet occupation forces to the cultural development was not similar to their own practice (apart from the brief periods of national revival policy of korenizatsiya, as arguably a means to locate "anti-national elements"). Instead, Korean nationalism was promulgated, even though with the use of "party line" rhetoric. Nationalist state propaganda also used film more masterfully than the Southern counterparts, producing a number of quality-pictures in Soviet style.

The Soviet monopoly on information is quite evident. To some extent it is the result of the absence of information for the Korean peninsula from the outside world since 1941 after the start of the War in the Pacific. It is quite possible that North Koreans were not aware that the U.S. defeated Japan in World War II, and not the Soviet Union (Armstrong 2003, p.93).

\section{Execution of propaganda in the context of political development of DPRK}

When writing on political life in Democratic People's Republic of Korea it is necessary to understand that a certain information barrier exists even today. DPRK, ussually refered to as North Korea, has established the socalled "hermit kingdom" preciselly during the researched period. However, certain information exists on the pre-war developments that tell us a story of political life first under the Soviet occupation and then of a presumably indipendent actor.

Such use of propaganda within this sphere of life is understood through the case-study of the rise of Kim Il-sung as a leader of DPRK. Evidently his position as a country's only leader was gradually formed after the deocupation of Korea by Japan in 1945 and the subsequent occupation of the peninsula by the USA and the USSR. His position was not always firm and the cult around his persona was formed by the means of propaganda.

The childhood and the youth years of the leader were the first attempts to create an information precedent after his arrival into North Korea after the entrance of Soviet troops. At the time his name was Kim Song-ju and various sources sometimes differ on actual dates. He is presumed to be born in 1912 to a farmer in Tae-dong Prefecture, South Pyongan Province that is near Pyongyang. His family moved to Manchuria after the March First Movement in 1919, a show of discontent of Koreans towards Japanese rule. The reason for the move is presented to be his father's involvement in the movement (Chong-Sik 1967, p.375). Chong-Sik Lee, one of the researchers 
on North Korea, claims this notion to be added by the communist apologists, since independent sources are unavailable.

Similarly, biographers allegedly credit him with joining of Comsomol (a Communist Youth organization) and a subsequent imprisonment for his revolutionary activities. This type of narrative is characteristic to most communist states of the time, having the intention to create a role model of a relentless revolutionary.

In his older years Kim Il-Sung is portrayed as to have headed the Comsomol movement by 1931 and his ascent into Communist Party, which by that time should have been absorbed by Chinese Communist Party. This notion is omitted in official propaganda as not to allow consumers to build any relations to the fact. However, "Although the Japanese consulate police in Chientao collected detailed information regarding the Korean Communist activities in Manchuria and much of these are extant, no record has been found to substantiate any of the dubious claims concerning Song-ju" (Chong-Sik 1967, p.375). Even though there is not so much information on the subject, at least not of credible origin, such discrepancies suggest a direct interference.

One of the other motives is a portrayal of Kim as a guerilla leader in the fight against Japanese rule. The anti-Japanese rhetoric is also inherent to prewar developments as a means to use nationalist tendencies to establish the regime, while in the aftermath it received a second place after anti-American. Kim's involvement in anti-Japanese activity is similarly over-emphasized in scope, leading to a bold fact invention like Korean People's Revolutionary Army (KPRA), a driving force of which he was supposed to be. His actual involvement could have only been marginal due to the absence of big Korean armed formations on the Chinese territory at the time. At the same time Soviet Red Army is credited with the liberation of North Korea, but with the help of Kim Il-sung's KPRA (Chong-Sik 1967, p.376). Naturally this narrative leads to an assumption of obvious position of the Kim. Similarly, words are carefully patterned as in the case with "liberation" instead of "occupation" by the Soviet Union. This story also includes "glorification" of Kim Il-sung's endeavors in Manchuria, where Japanese forces allegedly established a special unit to track down his group. This led him to escape to the Soviet Union in 1941, which can be regarded as a reason for his enthronement during the occupation.

In terms of his political ascension, Kim had at least two rivals in the names of Kim Tu-bong and Pak Hon-yong, both of them continuously fighting the oppressing regime since 1905 and 1919 respectively, enduring imprisonment and having contacts with Comintern. However, the reason may be similar to that of the USA in the regard to Syngman Rhee, as Kim Il-sung was already on the territory of the Soviet Union and certain agreements could have been established prior to the occupation. Subsequently this choice gave Kim an opportunity to become a secretary of the North Korean Central Bureau of the 
Korean Communist Party in October 1945, and then a premier of the DPRK and the chairman of the Korean Workers' Party in 1949.

The absence of clear understanding of the origin of the new leader among the populace called for the massive propaganda campaign to create a strong revolutionary figure, a campaign in its methods similar to those described in the works of E. Barneys and W. Lippmann. The position of the new leader was still shaky even within Korean Workers' Party as it still had some weight during the early years of North Korea. The period between 1953 and 1956 was decisive for the North Korean politics as the Korean War was concluded and Khrushchev launched de-Stalinization in the Soviet Union. The later fact prompted the party leadership to question the position of the sole leader of Korea, but the attempt was crushed swiftly. The crash of opposition became a reference point for the unbound development of DPRK's regime and the cultivation of the Kim Il-sung's image.

Image making of Kim Il-song was not ultimately bound to his performance as a guerilla leader, but also to his approach of dealing with day-to-day operations. The picture was drawn of a father, who knows everything and cares about his subjects. In line with the Cassirer's theory we can establish a certain myth to have been built in order to legitimize Kim's rule. Allegedly he used to study specifications of production before his numerous visits to the factories and villages, thus providing him with minimal knowledge to ask professional questions (Chong-Sik 1967, pp.379-381). This provided him with an image of having a "direct personal guidance". Additionally, his position was used as a way to gain more resources for the production, as he had power to influence providers. The generally low level of education resulted in connecting this fact to his "divine" powers or lucky charm properties thus confirming the myth status.

\section{Misuse of public relations in ROK}

From the initial stages of Republic of Korea's independence a political struggle within the country limited by the 38th Parallel was high. As was explained before, most of the propaganda work in the early stages of occupation was done by the occupying government itself. The early pre-war years of 1945-1947 were the time for the establishment of the Syngman Rhee as a future political leader. During this time a number of uprisings were conducted and suppressed by the government. This period is also charecterised by the highly-agressive atitude towards any left-oriented thinking.

ROK accepted anticommunism as the concept to overcome communist ideology, whereas it became an ideology of its own. A response to the ideological threats emanating from the North Korea was tested as general framework of state development.

Unlike in Norh Korea, South Korean political reality permited the existance of left-oriented political forces up until May of 1946 when the so-called 
"Jeongpansa Incident" happened, involving counterfeit efforts by leftists. After this event a full-scale suppression of the left-wing started (Il-Whan 2001, p.65). Gradually it resulted first in the creation (through the support of various leftist movements) and then gradual dissolution of Workers' Party that previously existend in South Korea in 1949. Inbetween another number of violent actions were undertaken by both communists and the government including the notorious Jeju island massacre.

USMAMGIC goal was to separate leftists from the rest of population attributing the connection to the Soviet Union or the communists overall. The Syngman Rhee government that was inaugurated on August 15, 1948 mostly followed the previous line of conduct in order to receive the support of the United States.

Even though South Korea at the time was prescribed property of a liberal democracy, the political realities showed that it was actually a suppressive police regime with the Syngman Rhee as its leader with powers just a bit short of authoritarian. Syngman Rhee is known for his speeches on anticommunism aimed at the local population that just received its long-desired independence.

The nationalistic discourse and anticommunism rhetoric reached its peak by the time of the Korean War. After the initial successes of Northern advance, the UN entered the conflict and briefly occupied a large chunk of the Northern land at the end of 1950. This short period was unexpected for many participants of the conflict, as the governing of the newly acquired territories was concerned.

The uncertain situation with governance showcased the South Korean attitude towards the issue. On some occasions South Korean officers ignored or misinterpreted the US Army's instructions having their ad hoc agenda implemented instead (Jong-yil 2005, p.537).

The situation can be described best as "The South Koreans behaved as if governing North Korea were their natural right. But they did not have any system - it was more a case of everyone assuming their own role and rights. The ROK military exercised certain prerogatives in civil administration. After it came the ROK "Youth Corps". Then followed such organizations as CIC, the military police and the railway police, each exercising its own powers. Over and above all was a supreme power in Pyongyang in the person of “Tiger" Brigadier (sic) Kim, who was allegedly personally appointed by Rhee himself, from whom he received instructions, according to information obtained by the US embassy" (Jong-yil 2005, p.540).

\section{Role of economic development of DPRK and ROK}

After the 15th of August 1945 and the collapse of the Japanese empire the two countries on Korean peninsula were created. The peculiarity of the event was not only in political consequences, but also in the economic 
development that was defined by the allegiance. The Japanese heritage in this regard was destroyed, former Korean elites were banished and factories were nationalized. A landlord system that previously existed was also destroyed and free land was disseminated among land-less masses. The taxation was lessened and certain peasant support was won by the new occupying regime and a communist government.

Among many changes, some structural basics were saved. The period of 1945-1950 is characterized by a market oriented approach, possibly a way so show superiority of the new governing bodies, but also as move to win even more support. However, a growth target was already set for 1947 and national plans were drawn subdivided into regional ones. This was to be achieved through the "voluntary" dependency or participation of farmers in local governments, which in turn were provided with the mission to enforce the quotas on each farmer. The farmers were organized into brigades for increased production and the quotas for different product types were introduced gradually (Kimura 1999, pp.73-74).

This system in many regards is reminiscent of that of the Soviet Union's collectivization efforts. The People's Committee at the time informed that the participation in such groups was voluntary, however, in reality it was enforced and a state purchase quota was present, thus creating a fissure between reality and a perceived image of this act.

The planned economy of the militarist Japan since then was in many cases continued by using similar 5-year plans and proceeding with goal-based system. At the same time People's Committee was ordering local authorities to oversee the movement to surpass plans. To some extent it became a reason for over-assessment of harvests and thus the increase in tax rates (Kimura 1999, p.75). Overall the system was built to suppress the individual powers of farmers and to enforce collective approach. The land reform that allowed peasants to use land was in many cases a propagandist construct depicted as to glorify the regime, as in reality the land changed hands from major landowners to the state-owned enterprise, also comparable to the situation towards the end of Japanese rule (Kimura 1999, p.77).

North Korea also used similar approach in relation to the industry sector. As already mentioned, it was nationalized with the introduction of stateownership. Plans (goal of quantity over quality) were introduced and prices were controlled. Prior to communist control, Japan has already molded the economy as to fit the wartime needs, and this feature was only expanded gradually. State goals were given lead by the notion of collectivization thus diminishing individual freedoms. In the case of North Korea the state goal was evident as was demonstrated by the 1950 invasion of the South. After the end of the war and up to 1960 the last market liberties of small-scale industries were eliminated and the collectivization lost a liberal overtone. 
What is interesting in this case is that the collectivization of farmers and nationalization of industries was conducted under accompaniment of various "movements" like that of Chollima, emphasizing on harder work for the prosperity of the state. A militarist nature of Kim Il-sung rule was also evident in this practice as these initiatives brought about an idea of a "battle" for some government-conceived goal. Psychologically, the system worked as to subject a human being under the influence of state and promoting the well being of state as superior to that of an individual. Therefore, individuals were urged to "push" harder and achieve more by the state, but the perception was that such movement was only natural in the existing conditions. As in the case of E. Barneys, the actor was using a complex system of values to achieve his goals, but with the sole exception that the state was also a direct creator of the said values that were then used.

South Korea practiced an open market economy, which resulted in a lagged development initially. From the start, its position was worse than that of the North because of a more agricultural structure of the economy, while the North was already heavily industrialized during the colonial times. This development heavily influenced propaganda against North Korea in the years to come. For a long period South Korean economy was inferior to the North's. Even though a certain propaganda campaigns existed to criticize adversary's decisions in agriculture and industry, the actual achievements of the Southern part of the Korean peninsula were rather marginal.

\section{Conclusion}

Korean peninsula of 1945-1960 is a unique example in the study of propaganda, due to the existence of two rather structurally different regimes that extensively and continuously used this practice against each other. The relations between ROK and DPRK were non-existent as they were both formed by and then became heavily reliant on occupying powers. Propaganda as a means of deception is a complex concept developed through the combination of language capabilities and misconceptions, social communication and public relations.

This attests to the idea that propaganda on a theoretical level is not just a separate practice, but also a phenomenon that is only explained through the number of psychological influences through the verbal and visual language as well as public relations.

Throughout the period various theoretical conditions were confirmed, as in the case of mythologization of North Korean leadership and the use of social groups to marginalize public in order to control it. Consequently, a degree of propagandistic pressure changed dramatically. Pre-war period is characterized with high domestic propagandist activity in hope of facilitating public support or subject the public to the will of the state. This diversified 
approach had a certain success in rallying strong support of both societies by discovering the key social groups. The time of war is defined by the introduction of the concept of dehumanization and the change in rhetoric from the Japanese threat to the US or USSR respectively, but continuing the idea of "one nation - two states". The aftermath of the active conflict brought about the general focus on domestic propaganda and legitimization of the regimes while keeping "neighboring threat" as a mobilization mechanism.

Certain features may be defined to explain this change, starting with the ideologies of the respective states and geopolitical conditions. Even though the research confirmed the change in the aim of messages within the conflict (extensive use of symbols, images, myths, historic narratives and personified idols), the methods and means of the practice did not change, but were rather used in different proportions.

The process of rapprochement was not started during these years as well as no initiatives indicating potential improvement (or the establishment) of the relations of DPRK and ROK. At the same time it is possible to say that educational systems laid down the ideological structures for correspondingly communist and anticommunist development of youth. However, the later issue should be better explained through the promising study of the ensuing periods.

\section{References}

Armstrong, C.K., 2003. The Cultural Cold War in Korea, 1945-1950. The Journal of Asian Studies, 62(1), pp.71-99.

Baron, Nick. 2004. Stalinist Planning As Political Practice: Control And Repression On The Soviet Periphery, 1935-1938. Europe-Asia Studies, 56 (3), pp.439-462.

Bernays, E., 2004. Propaganda. New York: Ig Publishing.

Cassirer, E. and Langer, S.K., 1946. Language and Myth. New York: Dover Publications.

Chong-Sik, L., 1967. Kim Il-song of North Korea. Asian Survey, 7(6), pp.374-382.

Gelb, Michael. 1995. An Early Soviet Ethnic Deportation: The Far-Eastern Koreans. Russian Review, 54 (3), pp.389-412.

Hyung-Chan, K., 1969. Ideology and Indoctrination in the Development of North Korean Education. Asian Survey, 9(11), pp.831-841.

Il-Whan, O., 2001. Anticommunism and the National Identity of Korea in the Contemporary Era: With a Special Focus on the USAMGIK and Syngman Rhee Government Periods. The Review of Korean Studies, 14(3), pp.61-100.

Jong-yil, R., 2005. Governing North Korea. Some Afterthoughts on the Autumn of 1950. Journal of Contemporary History, 40(3), pp.521-546.

Kimura, M., 1999. From Fascism to Communism: Continuity and Development of Collectivist Economic Policy in North Korea. The Economic History Review, 52(1), pp.69-86. 
Lippmann, W., 1965. Public Opinion. New York: Free.

Merriam-Webster Dictionary, n.d. Definition of Propaganda. Springfield: MerriamWebster. Available at: < http://www.merriam-webster.com/dictionary/ propaganda $>$ [Accessed 15 October 2015].

Oliver, R.T., 1954. A Brief for Korea. Annals of the American Academy of Political and Social Science, 294, pp.33-41.

Oxford Learner's Dictionary, 2016. Propaganda: Definition of Propaganda in Oxford Dictionaries (Thesaurus of English). Oxford: Oxford University Press. Available at: < http://www.oxfordlearnersdictionaries.com/definition/english/propaganda> [Accessed 15 October 2015].

Pratkanis, A.R. and Aronson, E., 1992. Age of Propaganda: The Everyday Use and Abuse of Persuasion. New York: W.H. Freeman.

Shaw, T., 1999. The Information Research Department of the British Foreign Office and the Korean War, 1950-53. Journal of Contemporary History, 34(2), pp.263-281.

The American Association for Public Opinion Research, 1951. Psychological Warfare in Korea, The Public Opinion Quarterly, 15(1), pp.65-75.

\section{About Author}

\section{Oleksii ZHYVORA}

$\mathrm{He}$ is a Bachelor of Political Science from Taras Shevchenko National University of Kyiv, currently pursuing master's degree at Vytautas Magnus University in East Asia Region Studies program. The author became interested in studying media and propaganda in particular, after witnessing the events of 2013-2014 Euromaidan revolution in Ukraine and the following military intervention. His current area of interest lies within the study of the effects of propaganda on Korean society in the aftermath of Korean War of 1950-1953. 